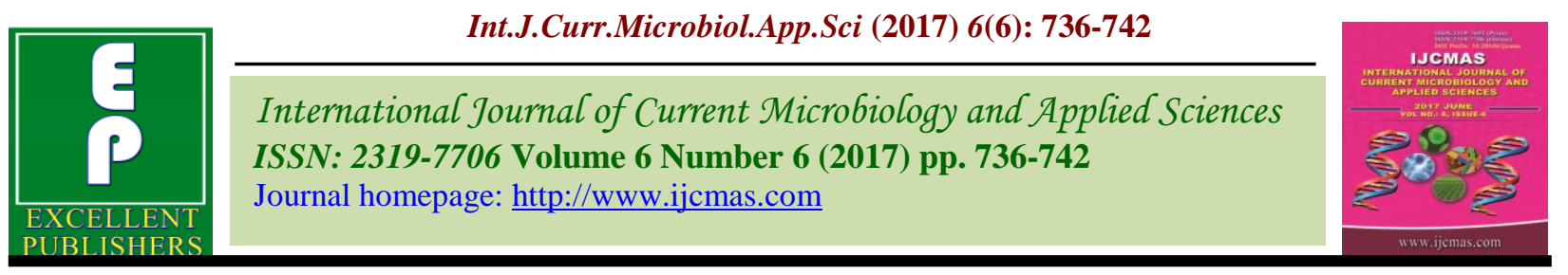

Original Research Article

https://doi.org/10.20546/ijcmas.2017.606.087

\title{
Effect of Organic Manures and Molybdenum on Growth, Yield and Quality of Groundnut
}

\author{
Shankar Lal Choudhary ${ }^{1}$, O.P. Sharma ${ }^{1}$, M.K. Gora ${ }^{2}$ and R.R. Choudhary ${ }^{3}$ \\ ${ }^{1}$ Department of Agronomy, S.K.N. College of Agriculture (SKNAU) Jobner, \\ Jaipur (Rajasthan), India \\ ${ }^{2}$ CSAUAT- Kanpur (Uttar Pradesh), India \\ ${ }^{3}$ Rajasthan Agriculture Research Institute, (SKNAU) Jobner, Jaipur (Rajasthan), India \\ *Corresponding author
}

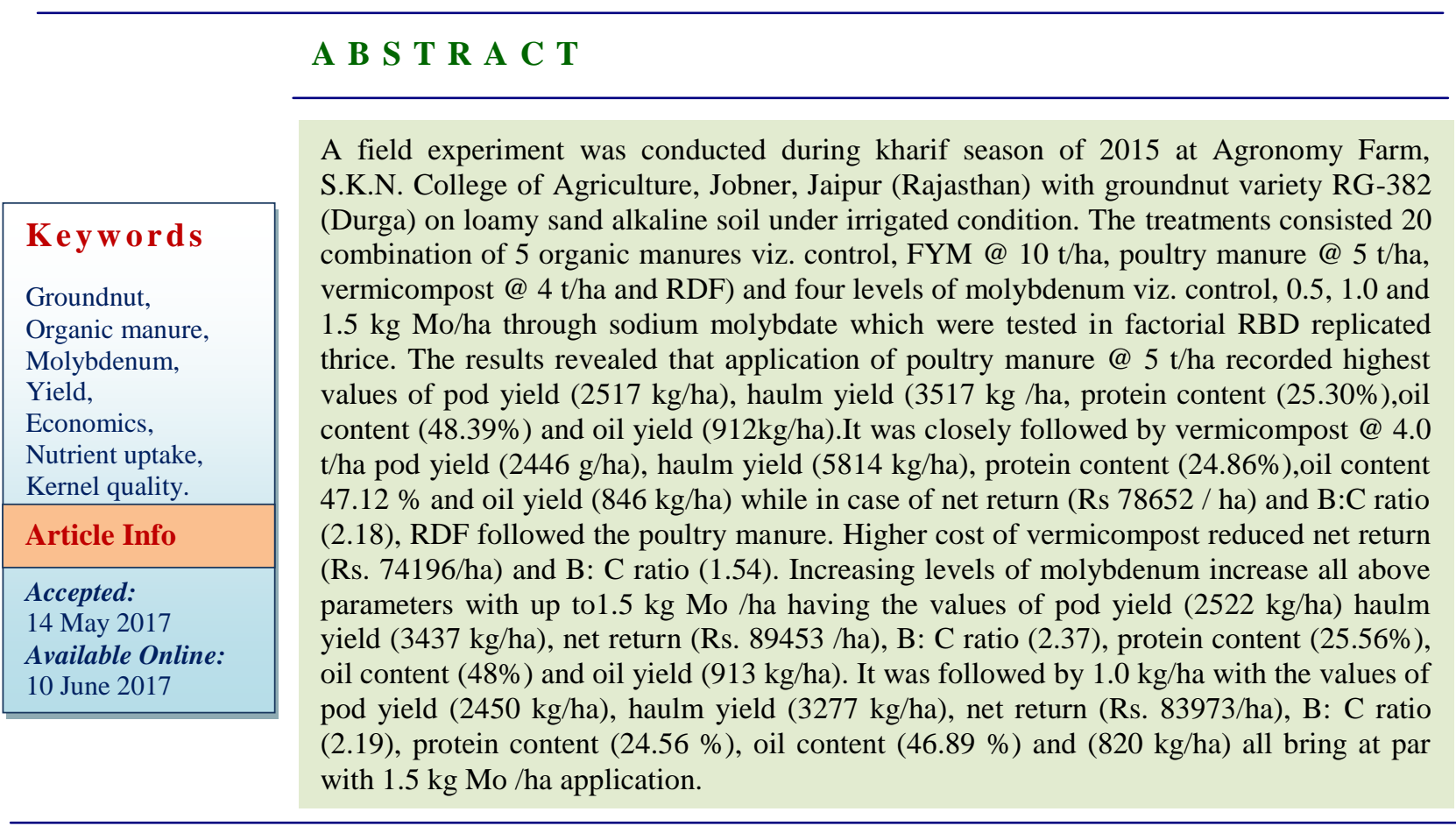

\section{Introduction}

Groundnut is an important oilseed crop of India while occupies the first place, both in regard to the area and the production in the word. In India, In India, groundnut was cultivated on an area of $5.53 \mathrm{~m}$ ha with production of $9.67 \mathrm{~m} \mathrm{t}$ and productivity of $1750 \mathrm{~kg} / \mathrm{ha}$ during 2013-14 (AICRPG, 2015). The important groundnut producing states in the country are Gujarat, Andhra Pradesh,
Tamil Nadu, Karnataka, Rajasthan and Maharashtra accounting for nearly $90 \%$ of the area and $89.3 \%$ total production of groundnut in the country. Organic manure are found to increase the groundnut productivity with maintaining soil health. Among those, Vermicompost is a prime source of macro and micro nutrients in chelated form and fulfills the balanced nutrient requirement of crops for 
longer period. Poultry manure is another important source of nutrients which plays direct role in plant growth. Importance of FYM in crop production and soil fertility management is well known. Among micronutrient molybdenum is an important micronutrient reported deficient in Indian soils. Molybdenum plays a significant role in various enzymatic and physiological activities of plants with obvious role in nitrogen fixation through root nodules in leguminous crops. Keeping in to consideration the above points, the present study was undertaken.

\section{Materials and Methods}

The present experiment was conducted on Agronomy farm, S.K.N. College of Agriculture, Jobner, Jaipur (Rajasthan) during kharif season of 2015 with groundnut variety RG-382 (Durga) which is semi-spreading, bold seeded and 128-133 days duration. The experimental soil was loamy sand in texture and alkaline in reaction with $8.3 \mathrm{pH}$. Having $0.17 \%$ organic carbon, $132 \mathrm{~kg} / \mathrm{ha}$ available $\mathrm{N}, 18 \mathrm{~kg} / \mathrm{ha} \mathrm{P}_{2} \mathrm{O}_{5}, 144 \mathrm{~kg} / \mathrm{ha}$ available $\mathrm{K}_{2} \mathrm{O}$ and $0.4 \mathrm{ppm}$ available molybdenum.

Crop was raised under irrigated condition by tubewell flowing slightly saline water. The treatment consisted 20 combinations of 5 organics/ fertilizers viz. Control, FYM @ 10 t/ha, poultry manure @ 5 t/ha, Vermicompost @ $4 \mathrm{t} / \mathrm{ha}$ and $\mathrm{RDF}\left(25 \mathrm{~kg} \mathrm{~N}+60 \mathrm{~kg} \mathrm{P}_{2} \mathrm{O}_{5}\right)$ and four levels of molybdenum viz. $0,0.5,1.0$ and $1.5 \mathrm{~kg} / \mathrm{ha}$. All 20 treatment combinations were tested in randomized block design replicated thrice. Organic manure before application were analysed for $\mathrm{N}, \mathrm{P}, \mathrm{K}$ contents. FYM, poultry manure and vermicompost contained $0.55: 0.25: 0.50$, $1.20: 1.15: 0.75$ and $1.40: 0.72: 1.07$ percent $\mathrm{N}: \mathrm{P}: \mathrm{K}$, respectively.

Molybdenum was applied through sodium molybdate containing $39 \%$ molybdenum.
Required quantity of organic manures and molybdenum as per treatment plots were drilled in deep furrows $45 \mathrm{~cm}$ apart and this process was just followed by seed showing @ $80 \mathrm{~kg} / \mathrm{ha}$ in same furrows through kera method and finely the planking was done on same day of 27th June, 2015. Besides presowing irrigation, the crop was irrigated thrice at all critical stages. Other then treatments, the crop was raised as per recommended package of practices for the area. At maturity, crop was harvested on 28.10.2015.

Besides irrigations, crop also received 406 $\mathrm{mm}$ rains during to life cycle. To evaluate the treatments effect the observations were recorded at the stage of crop harvested on plant stand, growth characters, yield attributes and yield. Nutrient contents, uptake, quality traits and economics were also worked out. Data recorded on different crop characters were analyzed statistically as per the procedure given by Panse and Sukhatme (1985).

\section{Results and Discussion}

Plant stand per meter row length was not influenced significantly by different treatments (Table 1). It shows that effect of treatments on other plant characters remained independent from plant stand.

\section{Growth and Yield Attributes}

The data presented in table 1 indicate that plant height, number of branches/plant, root nodules and their dry weight, number of pods/plant, kernels/pod, 100-kernal weight shelling percentage were recorded significantly higher under than application of poultry manure and vermicompost than other treatments of organics/fertilizers. The treatments of FYM and RDF improved all above crop parameters significantly over control. The beneficial effect of poultry 
manure and vermicompost on growth and yield attributes may probably due to enhanced supply of macro as well as micro nutrients during entire crop growing season which led to better root development, robust seedling growth, higher assimilation of food and its subsequent partitioning in sink. The availability and optimum regular supply of plant nutrients might have favorably influenced the flowering and kernel formation which ultimately increased pods/plant, kernels/pod, seed index and shelling per cent. Those results are in conformity with those of Singh (2000) and Marimutha et al., (2002).

Increasing levels of Mo application increase all growth and yield attributes with up to highest dose of $1.5 \mathrm{~kg} \mathrm{Mo} / \mathrm{ha}$ but increase beyond $1.0 \mathrm{~kg} \mathrm{Mo} / \mathrm{ha}$ was not found significant in any case. It might be due to the fact that Mo is a constituent of enzyme nitrogenase which is essential for the process of symbiotic $\mathrm{N}_{2}$ fixations.

This unique role of Mo in enhancing nitrogen fixation might have increased the nitrogen availability to crop plants for efficient growth and development.

The improvement in photosynthesis and carbohydrate metabolism resulting into greater formation of photosynthetic and metabolites in source and later on translocated in the newly formed sinks which ultimately increased pods/plant, kernels/pod and seed index. These results are in agreement with the findings of Shivkumar and kumutha (2003).

\section{Yield}

The treatments of poultry manure and vermicompost being at par produced significantly higher pod yield, biological yield as well as haulm yield than other treatments (Table 1). FYM and RDF treatments gave significantly higher groundnut yield than control. The treatment of poultry manure, vermicompost, FYM and RDF increased pod yield over control treatment by the margins of $580,509,293$ and $330 \mathrm{~kg} / \mathrm{ha}$ or $29.9,26.3$, 15.1 and $17.0 \%$ respectively. Those increases might be attributed to various yield attributes which are behaved similarly under different treatments and their accumulated effect may probably increase the pod yield over control. Almost similar increase was observed in biological and haulm yields under different treatments over control which might be attributed to growth characters.

The better yield performance under poultry manure and vermicompost application may be explained due to increase activities of $\mathrm{N}$ fixing bacteria and increased rate of humification. Humic acid in poultry manure and vermicompost may enhanced the availability of both native and added micronutrients in soil, thus improved plant growth, yield attributes and yield. These results corroborate with the finding of Chaudhari et al., (2015).

Increasing levels of Mo application increased groundnut yield linearly up to highest dose of $1.5 \mathrm{~kg} \mathrm{Mo} / \mathrm{ha}$ but the margin of increase in yield beyond $1.0 \mathrm{~kg} \mathrm{Mo} / \mathrm{ha}$ was not found significant in any case (Table 1). The application of $0.5,1.0$ and $1.5 \mathrm{~kg} \mathrm{Mo} / \mathrm{ha}$ increased pod yield over control by the margins of 292,522 and $594 \mathrm{~kg} / \mathrm{ha}$ or 15.1 , 27.1 and $30.8 \%$, respectively. Almost similar increase was observed in biological and haulm yields due to increased Mo application.

Such yield increases with increase in Mo application might be due to increased growth characters and yield attributes because of its unique role in enhancing $\mathrm{N}$-fixation, thereby increasing $\mathrm{N}$ availability to plants for efficient growth and development which might have enhanced photosynthesis and synthesis other metabolites for plant use. Similar finding were reported by Caires and Rosolam (2000). 
Table.1 Effect of organic manure, inorganic fertilizers and rates of molybdenum application on growth, yield attributes, yield economics of groundnut

\begin{tabular}{|c|c|c|c|c|c|c|c|c|c|c|c|c|c|c|c|}
\hline \multirow[t]{2}{*}{ Treatments } & \multirow{2}{*}{$\begin{array}{l}\text { Plant } \\
\text { stand per } \\
\text { m row }\end{array}$} & \multicolumn{4}{|c|}{ Growth characters } & \multicolumn{5}{|c|}{ Yield attributes } & \multicolumn{3}{|c|}{ Yield (kg/ha) } & \multicolumn{2}{|c|}{ Economics } \\
\hline & & Plant & $\begin{array}{l}\text { No. of } \\
\text { branches } \\
\text { per plant }\end{array}$ & $\begin{array}{l}\text { No. of } \\
\text { Nodules } \\
\text { per } \\
\text { plant }\end{array}$ & $\begin{array}{l}\text { Dry wt. } \\
\text { of nodules } \\
\text { per } \\
\text { plant }(\mathrm{g})\end{array}$ & $\begin{array}{l}\text { No. } \\
\text { of } \\
\text { pods/ } \\
\text { plant }\end{array}$ & $\begin{array}{l}\text { No. of } \\
\text { kernels/ } \\
\text { pod }\end{array}$ & $\begin{array}{l}100- \\
\text { kernel } \\
\text { wt.(g) }\end{array}$ & $\begin{array}{l}\text { Harvest } \\
\text { Index } \\
(\%)\end{array}$ & $\begin{array}{l}\text { Shelling } \\
(\%)\end{array}$ & Pods & Biological & Haulms & $\begin{array}{l}\text { Net } \\
\text { return } \\
\text { (Rs./ha) }\end{array}$ & $\begin{array}{l}\mathrm{B}: \mathrm{C} \\
\text { ratio }\end{array}$ \\
\hline \multicolumn{16}{|l|}{$\begin{array}{l}\text { Organic } \\
\text { manures/ } \\
\text { Fertilizers }\end{array}$} \\
\hline Control & 7.42 & 18.90 & 15.47 & 50.20 & 91.32 & 16.65 & 1.02 & 51.23 & 41.52 & 61.04 & 1937 & 4657 & 2720 & 65700 & 2.03 \\
\hline FYM @ 10 t/ha & 7.19 & 22.13 & 17.65 & 57.37 & 102.14 & 21.72 & 1.53 & 55.07 & 41.96 & 66.36 & 2230 & 5304 & 3074 & 75301 & 2.01 \\
\hline PM @ 5 t/ha & 7.29 & 26.80 & 20.37 & 67.16 & 111.48 & 23.90 & 1.92 & 62.32 & 41.64 & 73.61 & 2517 & 6034 & 3517 & 90488 & 2.45 \\
\hline VC@ 4 t/ha & 7.41 & 25.20 & 21.90 & 63.37 & 107.72 & 25.54 & 1.82 & 59.87 & 41.99 & 72.12 & 2446 & 5814 & 3368 & 74196 & 1.54 \\
\hline RDF (N25 P60) & 7.39 & 23.10 & 18.07 & 58.72 & 104.58 & 21.78 & 1.64 & 55.61 & 41.88 & 66.60 & 2267 & 5403.00 & 3136 & 78652 & 2.18 \\
\hline SEm \pm & 0.33 & 0.65 & 0.62 & 1.53 & 2.16 & 0.73 & 0.05 & 1.18 & 1.16 & 1.69 & 61 & 148 & 69 & 2234 & 0.05 \\
\hline C.D. $(p=0.05)$ & NS & 1.87 & 1.77 & 4.38 & 6.18 & 2.09 & 0.15 & 3.38 & NS & 4.84 & 174 & 425 & 198 & 6397 & 0.20 \\
\hline \multicolumn{16}{|l|}{ Molybdenum } \\
\hline Control & 7.33 & 20.36 & 15.06 & 51.54 & 92.21 & 17.90 & 1.27 & 51.29 & 40.31 & 61.17 & 1928 & 4790 & 2862 & 60423 & 1.65 \\
\hline $0.5 \mathrm{~kg} \mathrm{Mo} / \mathrm{ha}$ & 7.56 & 22.34 & 17.85 & 58.04 & 99.91 & 21.01 & 1.52 & 55.79 & 41.64 & 66.32 & 2220 & 5296 & 3076 & 73619 & 1.96 \\
\hline $1.0 \mathrm{~kg} \mathrm{Mo} / \mathrm{ha}$ & 7.16 & 24.34 & 20.21 & 62.45 & 108.54 & 23.74 & 1.71 & 59.13 & 42.52 & 71.13 & 2450 & 5727 & 3277 & 83973 & 2.19 \\
\hline $1.5 \mathrm{~kg} \mathrm{Mo} / \mathrm{ha}$ & 7.32 & 25.87 & 21.64 & 65.41 & 113.12 & 25.01 & 1.83 & 61.08 & 42.73 & 73.16 & 2522 & 5959 & 3437 & 89453 & 2.37 \\
\hline SEm \pm & 0.30 & 0.58 & 0.55 & 1.37 & 1.93 & 0.65 & 0.05 & 1.06 & 1.04 & 1.51 & 54 & 133 & 62 & 1998 & 0.06 \\
\hline C.D. $(p=0.05)$ & NS & 1.67 & 1.58 & 3.92 & 5.53 & 1.87 & 0.14 & 3.03 & NS & 4.33 & 156 & 380 & 177 & 5721 & 0.19 \\
\hline
\end{tabular}

PM-Poultry manure; VC- Vermicompost 
Table.2 Effect of organic manure, inorganic fertilizers and rates of molybdenum application on contents and uptake of nutrients and quality parameters of groundnut

\begin{tabular}{|c|c|c|c|c|c|c|c|c|c|c|c|c|c|c|c|}
\hline \multirow[t]{3}{*}{ Treatments } & \multicolumn{8}{|c|}{ Nutrient content } & \multicolumn{4}{|c|}{ Nutrient uptake whole crop } & \multicolumn{3}{|c|}{ Kernels Quality } \\
\hline & \multicolumn{2}{|l|}{$\mathrm{N}(\%)$} & \multicolumn{2}{|l|}{$\mathrm{P}(\%)$} & \multicolumn{2}{|l|}{$\mathrm{K}(\%)$} & \multicolumn{2}{|c|}{ Mo (PPM) } & \multirow{2}{*}{$\begin{array}{l}\mathrm{N} \\
(\mathrm{kg} / \mathrm{ha})\end{array}$} & \multirow{2}{*}{$\begin{array}{l}\mathrm{P} \\
(\mathrm{kg} / \mathrm{ha})\end{array}$} & \multirow{2}{*}{$\frac{K}{(\mathrm{~kg} / \mathrm{ha})}$} & \multirow{2}{*}{$\begin{array}{l}\text { Mo } \\
\text { (g/ha) }\end{array}$} & \multirow{2}{*}{$\begin{array}{l}\text { Protein } \\
(\%)\end{array}$} & \multirow{2}{*}{$\frac{\text { Oil }}{(\%)}$} & \multirow{2}{*}{$\begin{array}{l}\text { Oil } \\
\text { Yield } \\
\text { (kg/ha) }\end{array}$} \\
\hline & Kernel & Haulm & Kernel & Haulm & Kernel & Haulm & kernel & Haulm & & & & & & & \\
\hline \multicolumn{16}{|l|}{$\begin{array}{l}\text { Organic } \\
\text { manures/ } \\
\text { Fertilizers }\end{array}$} \\
\hline Control & 3.17 & 1.32 & 0.820 & 0.140 & 0.405 & 1.207 & 4.16 & 1.24 & 98.06 & 19.79 & 40.77 & 11.47 & 19.80 & 41.67 & 501.15 \\
\hline $\begin{array}{l}\text { FYM @ } 10 \\
\text { t/ha }\end{array}$ & 3.71 & 1.61 & 0.832 & 0.148 & 0.411 & 1.237 & 4.41 & 1.32 & 133.25 & 23.21 & 47.30 & 13.95 & 23.18 & 44.02 & 662.60 \\
\hline PM@ 9 t/ha & 4.05 & 1.93 & 0.867 & 0.156 & 0.418 & 1.311 & 4.95 & 1.47 & 171.13 & 27.43 & 56.76 & 17.69 & 25.30 & 48.39 & 912.01 \\
\hline VC@ @ t/ha & 3.98 & 1.87 & 0.820 & 0.151 & 0.414 & 1.303 & 4.77 & 1.43 & 161.56 & 26.07 & 54.14 & 16.56 & 24.86 & 47.12 & 845.50 \\
\hline $\begin{array}{l}\text { RDF (N25 } \\
\text { P60) }\end{array}$ & 3.75 & 1.65 & 0.840 & 0.147 & 0.410 & 1.272 & 4.50 & 1.35 & 137.81 & 23.31 & 49.30 & 14.50 & 23.42 & 44.71 & 686.64 \\
\hline SEm \pm & 0.06 & 0.05 & 0.026 & 0.014 & 0.015 & 0.081 & 0.08 & 0.02 & 3.11 & 0.62 & 1.56 & 1.20 & 0.62 & 0.73 & 22.00 \\
\hline C.D. $(p=0.05)$ & 0.19 & 0.15 & NS & NS & NS & NS & 0.22 & 0.05 & 8.91 & 1.77 & 4.46 & 3.43 & 1.77 & 2.09 & 62.98 \\
\hline \multicolumn{16}{|l|}{ Molybdenum } \\
\hline Control & 3.26 & 1.4 & 0.760 & 0.140 & 0.405 & 1.194 & 4.18 & 1.23 & 103.81 & 19.11 & 42.07 & 11.63 & 20.38 & 41.03 & 491.82 \\
\hline $0.5 \mathrm{~kg} \mathrm{Mo} / \mathrm{ha}$ & 3.64 & 1.61 & 0.826 & 0.146 & 0.411 & 1.255 & 4.48 & 1.34 & 131.45 & 22.87 & 47.83 & 14.14 & 22.75 & 44.82 & 661.43 \\
\hline $1.0 \mathrm{~kg} \mathrm{Mo} / \mathrm{ha}$ & 3.93 & 1.79 & 0.861 & 0.152 & 0.414 & 1.294 & 4.72 & 1.41 & 156.28 & 26.12 & 52.66 & 16.27 & 24.56 & 46.89 & 819.93 \\
\hline $1.5 \mathrm{~kg} \mathrm{Mo} / \mathrm{ha}$ & 4.09 & 1.9 & 0.887 & 0.155 & 0.417 & 1.321 & 4.85 & 1.45 & 169.91 & 27.75 & 56.05 & 17.30 & 25.56 & 48.00 & 913.13 \\
\hline SEm \pm & 0.06 & 0.05 & 0.024 & 0.013 & 0.014 & 0.072 & 0.07 & 0.02 & 2.78 & 0.55 & 1.39 & 1.07 & 0.55 & 0.65 & 19.68 \\
\hline C.D. $(p=0.05)$ & 0.17 & 0.14 & $\mathrm{NS}$ & NS & NS & NS & 0.20 & 0.04 & 7.97 & 1.58 & 3.99 & 3.07 & 1.58 & 1.87 & 56.33 \\
\hline
\end{tabular}




\section{Economics}

The data presented in table 1 indicate that groundnut supplied with poultry manure @ 5 $\mathrm{t} / \mathrm{ha}$ resulted in significantly highest net return of Rs.90488/ha and B: C ratio of 2.45, whereas significantly lowest net return Rs. 65700/ha was recorded in control treatment. Significantly lowest B: C ratio of 1.54 was computed under vermicompost application highest net return and $\mathrm{B}$ : $\mathrm{C}$ ratio under poultry manure might be attributed to highest yield and lower cost of manure. Vermicompost could not compete with poultry manure in economics perhaps due to much higher cost of manure which reduced $\mathrm{B}$ : $\mathrm{C}$ ratio increased with increasing levels of Mo application significantly with up to $1.0 \mathrm{~kg} \mathrm{Mo} / \mathrm{ha}$ which might be attributed to crop yields. Though further increase in Mo up to $1.5 \mathrm{~kg} / \mathrm{ha}$ increased net return and $\mathrm{B}: \mathrm{C}$ ratio but margin of increase beyond $1.0 \mathrm{~kg} \mathrm{Mo} / \mathrm{ha}$ was not significantly. Thus, the dose of $1.0 \mathrm{~kg} \mathrm{Mo} / \mathrm{ha}$ proved to be the optimum from crop productivity and profitability points of view.

\section{Nutrient content and uptake}

The data presented in table 2 indicate that the contents of $\mathrm{N}$ and Mo in kernel and haulm of groundnut were significantly influenced by treatments. Among organic manures, poultry manure and vermicompost being at par showed significantly higher $\mathrm{N}$ and $\mathrm{Mo}$ contents in kernel and haulm both than other treatments. Trend was found similar in $\mathrm{P}$ and $\mathrm{K}$ contents but differences could not touch the level of significance. Increasing levels of Mo application increased $\mathrm{N}$ and Mo content in kernel and haulm both significantly with up to $1.0 \mathrm{~kg} \mathrm{Mo} / \mathrm{ha} . \mathrm{P}$ and $\mathrm{k}$ content also showed increase with up to $1.5 \mathrm{~kg} \mathrm{Mo} / \mathrm{ha}$ but without significant margins. It might be attributed to increased availability of nutrients in soil for plant use under the application of organic manures and increased doses of Mo application. Nutrient uptake was recorded highest under poultry manure closely followed by vermicompost with significant variation from other treatments (Table 2) FYM and RDF also increased nutrient uptake significantly over control. Increased application of Mo increased nutrient uptake with up to highest dose of $1.5 \mathrm{~kg} \mathrm{Mo} / \mathrm{ha}$ but increases beyond $1.0 \mathrm{~kg} \mathrm{Mo} / \mathrm{ha}$ was not found significant in any case. Such higher nutrient uptake values might be attributed to nutrient content in kernel and haulm and higher crop production under respective treatment of organic manures and Mo fertilization. Those finding are in agreement to dose of Reddy (2005).

\section{Quality Parameters}

The applications of poultry manure being at par with vermicompost, recorded significantly higher protein contain and oil content in kernel than other organic treatments (Table 2). FYM and RDF treatment being at par showed significantly higher protein and oil content than control. However, poultry manure recorded significantly highest oil yield followed by vermicompost while significantly lowest oil was recorded in control treatment. The protein content in kernel is in fact a manifestation of nitrogen concentration. It could be explained in terms of greater synthesis of amino acids for improvement in nitrogen content of pod and haulm. The increased kernel nitrogen resulted in higher protein content recorded with poultry manure and vermicompost use. Increase in oil content due to organic manure might be associated with increased availability of certain micronutrients in soil for plant use. These results are in agreement to the finding of Rao and Shaktawat (2001). Oil yield is the resultant of oil content and kernel yield, thus it was recorded highest under poultry manure followed by vermicompost. All quality parameters 
increased with increasing levels of Mo application up to highest of $1.5 \mathrm{~kg} \mathrm{Mo} / \mathrm{ha}$. However, margin of increase beyond $1.0 \mathrm{~kg}$ $\mathrm{Mo} / \mathrm{ha}$ was not found significant in protein and oil content (Table 2). The micronutrient molybdenum acts as an activator of some dehydrogenase and phosphate enzymes and co-factor in the synthesis of ascorbic acid. Further, nitrates are to be metabolized in amino acids and proteins, since, nitrogen is essential constituent of protein, increased $\mathrm{N}$ content led to higher protein content in kernels, significant increase in oil yield with up to highest dose of $1.5 \mathrm{~kg} \mathrm{Mo} / \mathrm{ha}$ might be attributed to combined effect of oil content in kernel and kernel yield.

The results of present study could be concluded that for higher productivity and profitability from groundnut cultivation, it should be supplied with poultry manure @ 5 t/ha along with optimum application of $1.0 \mathrm{~kg}$ molybdenum/ha. This combination also provides good quality produce.

\section{References}

AICRPG. 2015. Annual Report (Kharif, 2014) All India Coordinated Research Project on Groundnut. ICARDirectorate of Groundnut Research, Junagadh.

Caires, E.F. and Rosolam, C.A. 2000. Nodulation and nitrogen uptake by groundnut in response to lime, cobalt and molybdenum. Cientia Agricola, 57: 337-341.
Chaudahri, R., Sharma, O.P., Choudhary, C. and Choudhary, R.S. 2015. Effect of organic and inorganic sources of nutrients on growth characters and yield of groundnut (Arachis hypogaea L.). Res. Crops, 16(4): 663-668.

Kachot, N.A., Malvia, D.D., Solanki, R.M. and Sagarka, B.K. 2001. Integrated nutrient management in rainy season groundnut (Arachis hypogaea). Indian J. Agron., 46: 516-522.

Marimuthu, R., Babu, S. and Vairaram, K. 2002. Utility of different sources of vermicompost and its nutrient status on the growth and yield of groundnut. Legume Res., 25: 266-269.

Panse, V.G. and Sukhatme, P.V. 1985. Statistical methods for agric. Workers ICAR pub. New Delhi, p. 361.

Rao, S.S. and Shaktawat, M.S. 2001. Effect of organic manure, phosphorus and gypsum on growth, yield and quality of groundnut (Arachis hypogaea L.). Indian J. Plant Physiol., 6: 306-311.

Reddy, S.S. 2005. Effect of different organic manures on available NPK status and organic carbon after harvest of groundnut. Crop Res., 30(1): 26-29.

Shivakumar, U.I. and Kumutha, K. 2003. Effect of Rhizobium and molybdenum on nodulation yield and yield contributing characters of groundnut. $J$. Echobiol., 15: 451-455.

Singh, R.A. 2000. Feasibility of verminfarming in peanut (Arachis hypogaea) vegetable pea (Pisum sativum) cropping system. Indian J. Agron., 45(2): 257262.

\section{How to cite this article:}

Shankar Lal Choudhary, Sharma O. P., Gora M. K., Choudhary R. R.. 2017. Effect of Organic Manures and Molybdenum on Growth, Yield and Quality of Groundnut. Int.J.Curr.Microbiol.App.Sci. 6(6): 736-742. doi: https://doi.org/10.20546/ijcmas.2017.606.087 